\title{
Hubungan Antara Kebersyukuran Dengan Kebahagiaan Pada Guru Honorer
}

\author{
M. Khairullah, Nina Zulida Situmorang, Ahmad Muhammad Diponegoro \\ Universitas Ahmad Dahlan, Yogyakarta, Indonesia \\ Email: muhhairul12@gmail.com nzsitumorang@gmail.com tugasindi@ gmail.com
}

\begin{abstract}
This reseach aims to determine the relationship between thanksgiving and happiness in honorary teachers. The research method is a quantitative method. The data collection techniques used scale of gratitude and scale of happiness. The subjects of this research were 105 teachers of the State Elementary School in Masbagik sub-district, East Lombok district. The analysis technique used is Product Moment Correation analysis by using SPSS 23.00 For Windows. The result of data analysis showed that the coefficient of correlation was $R=0.690$ with a significance level of $0.000(p<0.01)$. This research indicated that the contribution which is given by gratitude to happiness is $47,6 \%$, it means the relationship between the variables of gratitude and happiness for honorary is very significant.
\end{abstract}

Keywords: Gratefulness, Hapiness, Honorary Teacher

\begin{abstract}
Abstrak
Penelitian ini bertujuan untuk mengetahui hubungan antara kebersyukuran dengan kebahagiaan pada guru honorer. Metode penelitian yang digunakan adalah metode kuantitatif. Alat pengumpulan data menggunakan skala kebersyukuran dan skala kebahagiaan. Subjek dalam penelitian ini adalah guru honorer SekoIah Dasar Negeri di kecamatan Masbagik kabupaten Lombok Timur sebanyak 105 orang. Teknik analisis yang digunakan adalah analisis Product Moment CorreIation dengan bantuan SPSS 23.00 For Windows. HasiI anaIisis data menunjukan koefisien koreIasi sebesar $\mathrm{R}=0,690$ dengan taraf signifikansi sebesar $0,000(\mathrm{p}<0,01)$. Hasil peneIitian ini menunjukan bahwa sumbang yang diberikan kebersyukuran terhadap kebahagiaan adalah sebesar 47,6\%, hal ini menunjukan adanya hubungan yangsangat signifikn antar variabeI kebersyukuran dengan kebahagiaan terhadap guru honorer.
\end{abstract}

Kata kunci: Kebersyukuran, Kebahagiaan, Guru Honorer

\section{Pendahuluan}

Guru adalah pendidik profesional yang tugas utamanya untuk mendidik, mengajar, mengarahkan, melatih, membimbing, menilai, dan mengevaluasi peserta didik pada pendidikan anak usia dini. Jalur pendidikan formal mencakup pendidikan dasar, menengah, dan atas [1]. Guru honorer juga mendapat diskriminasi atau perbedaan dengan jabatan pada guru yang sudah mendapatkan gaji tetap yaitu guru Pegawai Negeri Sipil (PNS) [2]. Disaat menjalankan tugasnya, guru PNS digaji sesuai standar yang disesuaikan oleh pemerintah dengan masa kerja dan golongan [3], sedangkan guru honorer adalah guru yang bekerja pada beberapa sekolah negeri atau swasta yang sampai saat ini belum memiliki standar gaji yang menitikberatkan pada bobot jam pelajaran, tingakatan jabatan, dan tanggung jawab pada masa depan peserta didiknya [4]. Kebijakan kementerian pendidikan dan kebudayaan saat ini memberikan pengaruh yang cukup besar terhadap menjamurnya guru-guru honorer [5].

Berdasarkan hasil wawancara di lapangan pada tanggal 12/11/2019, dengan beberapa subjek diperoleh informasi bahwa menjadi guru honorer itu tidaklah mudah, selain terkait dengan gaji yang sangatlah minim dan jam mengajarnya pun sama dengan jam mengajar guru yang telah diangkat menjadi PNS, gaji yang mereka terima mulai dari Rp. 200.000 hingga Rp. 800.000 setiap bulannya, tergantung masa kerja dan jenis sekolahnya, otonom atau subsidi, serta beban kerja, subjek juga mengatakan untuk menambah finansialnya ia juga membuka jasa bimbingan belajar pada waktu sore karena jika hanya mengandalkan gaji sebagai guru honor jelas tidak akan mencukupi kebutuhan hidupnya. Subjek merasa putus asa dengan kehidupannya saat ini yang membuat subjek tidak bersemangat lagi dalam bekerja bahkan subjek mengatakan bahwa jika ada pekerjaan yang lebih baik dari guru honorer ia akan berhenti bekerja. subjek juga mengatakan menyesal kuliah di jurusan keguruan jika ternyata kehidupannya sebagai guru honorer tidak bahagia. Dari hasil wawancara juga didapatkan bahwa subjek selalu mendapatkan tekanan pada lingkungan kerja karena statusnya yang masih menjadi guru 
honorer dan harus melakukan tugas di luar dari jam pelajaran dan tugas pokoknya sebagai guru misalnya menginput data gaji dan membeli keperluan sekolah. Berdasarkan hasil wawancara tersebut maka disimpulkan bahwa guru honorer masih memiliki tingkat kebahagiaan yang rendah. Kebahagiaan merupakan konsep psikologis yang mengacu pada emosi positif yang dirasakan individu serta aktivitas-aktivitas positif yang disukai oleh individu-individu tersebut [6]. Selain itu kebahagiaan merupakan keadaan psikologis yang positif, ditandai dengan tingginya tingkat kepuasan hidup dan tingginya tingkat emosi positif serta rendahnya tingkat emosi negative [7].

Beberapa temuan penelitian terdahulu menjelaskan mengenai dampak positif kebahagiaan pada seorang individu. Seorang individu yang bahagia memiliki hubungan sosial yang baik, lebih menyenangkan dan lebih romantik [8]. kebahagiaan adalah indeks bagaimana individu menghabiskan hidupnya dari waktu ke waktu serta adanya kombinasi dari momen sementara yang dapat menimbulkan kesejahteraan dan kesehatan individu tersebut [9-10].

Penting bagi individu terutama guru honorer, untuk meningkatkan kebahagiaan dalam hidupnya, dan ada banyak faktor yang mempengaruhi kebahagiaan, salah satunya adalah kebersyukuran. Kebersyukuran adalah suatu bentuk emosi atau perasaan yang kemudian berkembang menjadi suatu sikap, perasaan, dan akhirnya akan mempengaruhi individu [10]. Salah satu ciri kebersyukuran adalah rasa cukup, kebersyukuran tidak hanya disebabkan rasa terimakasih terhadap suatu hadiah atau pemberian yang diterima, tetapi juga karena menerima perbuatan baik seseorang [11-12]. Dengan adanya tindakan tersebut tentunya akan membuat seorang makin percaya diri dan merasa bahagia [1316]. Berdasarkan paparan dan pendapat para ahli tersebut, peneliti meneliti tentang pengaruh kebersyukuran dan kebahagiaan pada guru honorer.

\section{Metode Penelitian}

Metode yang akan digunakan dalam penelitian ini adalah metode kuantitatif, alat pengumpulan data yang digunakan dalam penelitian ini menggunakan skala. Pengambilan data dilakukan secara langsung kepada guru honorer sebagai subjek dalam penelitian untuk mengisi skala. Dalam penelitian ini skala yang digunakan merupakan model dari skala likert. Skala yang menggunakan likert adalah skala kebersyukuran dan kebahagiaan. Skala model likert memiliki empat alternatif jawaban yang dipisahkan menjadikan pernyataan favorabel dan pernyataan unfavorabel.

Teknik sampling yang digunakan dalam penelitian ini adalah cluster random sampling. cluster random sampling yaitu teknik pengambilan sampel yang dilakukan dengan cara mengundi secara acak nama sekolah dasar negeri 1 sampai 45 di kecamatan Masbagik kabupaten Lombok timur yang dimana 26 nama sekolah yang keluar pada saat undian tersebut disimpan untuk dijadikan subjek penelitian sedangkan sisanya yang 19 nama sekolah tersebut dijadikan subjek try out.

Data yang diperoleh kemudian dianalisis dengan menggunakan analisis korelasi product moment yaitu prosedur yang digunakan untuk mengetahui ada tidaknya hubungan antara kebersyukuran dan kebahagiaan pada guru honorer. Perhitungan dalam menganalisis data penelitian dilakukan dengan menggunakan program komputer SPSS (statistical product or service solution) versi 23.00 for windows.

\section{Hasil dan Pembahasan}

Pada penelitian ini peneliti melakukan penelitian di pulau Lombok, Provinsi Nusa Tenggara Barat. Batas wilayah terbagi menjadi tiga yaitu Lombok timur, Lombok tengah dan Lombok barat. Wilayah Lombok Timur sendiri terdiri atas 21 kecamatan yaitu Aikmel, Jerowaru, Keruak, Labuhan haji, Lenek, Montong gading, Pringgabaya, Pringgasela, Sakra, Sakra timur, Sakra barat, Sambelia, Selong, Sembalun, Sikur, Sukamulia, Suralaga, Suwela, Terara, Wanasabe, Masbagik. Berikut hasil perhitungan data mengenai kebahagiaan dan kebersyukuran guru honorer:

A. Data Deskriptif Penelitian

1. Kebersyukuran

Kategorisasi kebersyukuran pada guru honorer dapat dilihat pada tabel berikut. 
Tabel 1. Kategorisasi kebersyukuran.

\begin{tabular}{|c|c|c|c|}
\hline \multirow{2}{*}{ Interval } & \multirow{2}{*}{ Kategori } & \multicolumn{2}{|c|}{ Subjek } \\
\hline & & Frekuensi & Persentase \\
\hline$X<60$ & Rendah & 12 & $11,43 \%$ \\
\hline $60 \leq X<70$ & Sedang & 77 & $73,33 \%$ \\
\hline $70>X$ & Tinggi & 16 & $15,24 \%$ \\
\hline \multicolumn{2}{|c|}{ Jumlah } & 105 & $100 \%$ \\
\hline
\end{tabular}

Berdasarkan hasil kategorisasi pada tabel 1 maka dapat disimpulkan bahwa dari keseluruhan jumlah subjek penelitian terdapat $12(11,43 \%)$ subjek yang memiliki kebersyukuran pada kategori rendah, 77 $(73,33 \%)$ subjek memiliki kebersyukuran pada kategori sedang dan $16(15,24 \%)$ subjek yang memiliki kebersyukuran pada kategori tinggi.

2. Kebahagiaan

Kategorisasi kebahagiaan pada pada guru honorer dapat dilihat pada tabel berikut.

Tabel 2. Kategorisasi kebahagiaan

\begin{tabular}{|c|c|c|c|}
\hline \multirow{2}{*}{ Interval } & \multirow{2}{*}{ Kategori } & \multicolumn{2}{|c|}{ Subjek } \\
\hline & & Frekuensi & Persentase \\
\hline$X<72$ & Rendah & 13 & $12,38 \%$ \\
\hline $72 \leq X<85$ & Sedang & 76 & $72,38 \%$ \\
\hline $85>X$ & Tinggi & 16 & $15,24 \%$ \\
\hline \multicolumn{2}{|c|}{ Jumlah } & 105 & $100 \%$ \\
\hline
\end{tabular}

Berdasarkan hasil kategorisasi pada tabel 2 maka dapat disimpulkan bahwa dari keseluruhan jumlah subjek penelitian terdapat $13(12,38 \%)$ subjek yang memiliki kebahagiaan pada kategori rendah, 76 $(72,38 \%)$ subjek memiliki kebahagiaan pada kategori sedang dan $16(15,24 \%)$ subjek yang memiliki kebahagiaan pada kategori tinggi.

\section{B. Uji Normalitas Sebaran}

Pengujian normalitas menggunakan teknik statistik one-sample Kolmogorov-Smirnov test. Pada uji statistik tersebut jika diperoleh nilai probabilitas sebesar 0,05 atau lebih $(\geq 0,05)$ maka data mengikut distribusi normal dan jika probabilitas lebih kecil $0,05(<0,05)$ maka data tidak mengikuti distribusi normal. Hasil uji normalitas masing-masing variabel disajikan pada tabel berikut.

Tabel 3. Hasil uji normalitas

\begin{tabular}{lccc}
\hline \multicolumn{1}{c}{ Variabel } & Skor KS-Z & Sig $(\mathrm{p})$ & Keterangan \\
\hline Kebersyukuran & 1,080 & 0,194 & Normal \\
Kebahagiaan & 0,785 & 0,568 & Normal \\
\hline
\end{tabular}

Hasil uji normalitas yang tersaji pada tabel 3 diatas menunjukkan bahwa variabel kebersyukuran memiliki $p=0,194(p>0,05)$ dan variabel kebahagiaan $p=0,568(p>0,05)$. Berdasarkan hasil uji normalitas tersebut maka dapat disimpulkan bahwa masing-masing variabel penelitian memiliki sebaran data yang terdistribusi normal.

\section{Uji Linearitas}

Pengujian lineraitas dilakukan dengan bantuan SPSS 23,00 for windows. Kriteria pengujian linieritas adalah jika nilai signifikansi pada linierity kurang dari 0,05 $(<0,05)$ dan deviation from linierity lebih 
besar dari 0,05 $(>0,05)$ maka hubungan antara variabel bebas dengan variabel terikat linier. Hasil uji linieritas terhadap masing-masing variabel disajikan pada table berikut:

Tabel 4. Hasil uji linieritas

\begin{tabular}{|c|c|c|c|}
\hline Variabel & $\begin{array}{l}\text { Deviation From } \\
\text { Linearity }(\mathrm{F})\end{array}$ & $\begin{array}{l}\text { Signifikansi } \\
\text { Linearity (p) }\end{array}$ & Keterangan \\
\hline $\begin{array}{l}\text { Kebersyukuran } \\
\text { kebahagiaan }\end{array}$ & 1,259 & 0,000 & Linier \\
\hline
\end{tabular}

Berdasarkan hasil analisis uji linieritas pada Tabel 4 di atas dapat disimpulkan bahwa pengaruh antara variabel kebersyukuran dan variabel kebahagiaan adalah linier.

\section{Uji Hipotesis}

Tabel 5. Hasil uji hipotesis

\begin{tabular}{cccc}
\hline Variabel & $R$ & $R$ Squared & Sig \\
\hline $\begin{array}{c}\text { Hubungan antara kebersyukuran dan } \\
\text { kebahagiaan }\end{array}$ & 0,690 & 0,476 & 0,000
\end{tabular}

Hasil korelasi antara variabel kebersyukuran dengan kebahagiaan diperoleh koefisien korelasi $R=$ 0,690 dengan taraf signifikansi $\mathrm{p}=0,000(\mathrm{p}<0,01)$. Berdasarkan hasil analisis sumbangan efektif yang dilakukan didapatkan hasil sumbangan efektif variabel kebersyukuran sebesar 47,6\%. Hasil analisis tersebut dapat disimpulkan bahwa hipotesis yang diajukan peneliti diterima, yaitu ada hubungan positif yang signifikan antara kebersyukuran dengan kebahagiaan pada guru honorer. Hubungan antara kebersyukuran dengan kebahagiaan positif, artinya jika kebersyukuran tinggi maka kebahagiaan akan tinggi, sebaliknya jika kebersyukuran rendah kebahagiaan akan rendah. Hasil analisis korelasi product moment menunjukan bahwa ada hubungan positif yang sangat signifikan antara kebersyukuran dengan kebahagiaan. Artinya semakin tinggi kebersyukuran maka semakin tinggi kebahagiaan dan sebaliknya, semakin rendah kebersyukuran maka semakin rendah pula kebahagiaan.

Hasil penelitian menunjukan hipotesis yang diajukan penulis dapat diterima yaitu ada hubungan antara kebersyukuran dengan kebahagiaan, yang artinya kebersyukuran merupakan salah satu faktor yang penting dalam meningkatkan kebahagiaan pada guru honorer. Pernyataan ini didukung oleh hasil penelitian yang dilakukan oleh [17] yang menunjukkan bahwa kebersyukuran berkorelasi positif terhadap kebahagiaan. Orang yang bersyukur akan cenderung merasakan kebahagiaan dan rasa syukur yang dirasakan tersebut juga mampu meningkatkan mood positif dalam dirinya. Individu memiliki sikap bersyukur yang tinggi maka akan mengindikasikan kebahagiaan, optimism, munculnya perilaku prososial, dukungan sosial dan sebagainya, sehingga syukur menjadi faktor yang melengkapi remaja dalam mencapai flourishing [18]. [19] juga menyatakan hal yang sama, bahwa syukur memotivasi generasi muda termasuk remaja untuk mencapai flourishing. Individu akan termotivasi untuk memenuhi kebutuhan dasar dari pengembangan diri, hubungan sosial dan komunitas. Syukur sebagai respon psikologis yang positif memberikan keuntungan interpersonal. Syukur menyebabkan munculnya emosi positif yang dapat membantu untuk mengeratkan hubungan sosial individu, dimana hubungan sosial juga merupakan aspek dari kebahagiaan [20] mendukung pernyataan ini dengan menyatakan bahwa syukur termasuk salah satu prediktor yang penting sekaligus unik dalam psychological well-being. Syukur memprediksi personal growth, hubungan positif dengan orang lain, tujuan hidup dan penerimaan diri. Meskipun begitu, syukur tidak memprediksi otonomi dan penguasaan lingkungan yang juga merupakan aspek psychological well-being atau kebahagiaan. 


\section{Kesimpulan}

Ada hubungan positif yang sangat signifikan kebersyukuran terhadap kebahagiaan. Semakin tinggi kebersyukuran maka semakin tinggi kebahagiaan. Begitu juga sebaliknya semakin rendah kebersyukuran maka semakin rendah pula tingkat kebahagiaan.

\section{Ucapan Terimakasih}

Penulis mengucapkan banyak terimakasih kepada pihak-pihak yang telah membantu penulis dalam menyelesaikan penelitian ini, khususnya pemerintah Lombok Timur yang telah mengizinkan peneliti melakukan penelitian ini.

\section{Daftar Rujukan}

[1] Anwar, Aep Saepul. "Pengembangan sikap profesionalisme guru melalui kinerja guru pada satuan pendidikan MTs Negeri 1 Serang." Andragogi: Jurnal Pendidikan Islam Dan Manajemen Pendidikan Islam, vol 2.1, pp. 147-173, 2020.

[2] Israpil, Israpil. "Pengelolaan dan Pemberdayaan Guru Non PNS Pada Madrasah Negeri di Kota Kendari." Educandum, vol 6.1, pp. 22-30, 2020

[3] Arifin, Wandi, dan Ridwan Arifin. "Asas Keadilan Upah Guru Honorer dalam Perspektif Hukum (Principle of Justice for Honorary Teacher Wages in a Legal Perspective)." Riau Law Journal, vol. 3.1, pp. 85-104, 2019.

[4] Kumorotomo, Wahyudi. "Tunjangan Kinerja Daerah (TKD) dan Upaya Peningkatan Kinerja Pegawai: Kasus Di Provinsi Gorontalo dan Provinsi DKI Jakarta." Civil Service Jurnal Kebijakan dan Manajemen PNS, vol. 5.1, pp. 21-34, 2011.

[5] Rohman, Miftahur. "Problematika Guru dan Dosen dalam Sistem Pendidikan di Indonesia." Cendekia: Jurnal Kependidikan Dan Kemasyarakatan, vol. 14.1, pp. 49-71, 2016.

[6] Meiza, Chairani. "Perbedaan kebahagiaan pada guru berstatus PNS dan honorer." Jurnal Psikologi, vol. 9.2, 2017.

[7] Aziz, Rahmat. "Pengalaman spiritual dan kebahagiaan pada guru agama sekolah dasar." Proyeksi: Jurnal Psikologi, vol. 6.2, pp. 1-11, 2021.

[8] Hamdan, Stephani Raihana. "Happiness: Psikologi Positif Versus Psikologi Islam." UNISIA, vol. 38.84, pp. 1-14, 2020.

[9] Ramdhani, Neila, Supra Wimbarti, and Yuli Fajar Susetyo. Psikologi untuk Indonesia tangguh dan bahagia. UGM PRESS, 2018.

[10] Murisal, Murisal, and Trisna Hasanah. "Hubungan Bersyukur dengan Kesejahteraan Subjektif pada Orang Tua yang Memiliki Anak Tunagrahita di SLB Negeri 2 Kota Padang." KONSELI: Jurnal Bimbingan dan Konseling (E-Journal), vol. 4.2, pp. 81-88, 2017.

[11] Mangansige, Irmanuelan, and Doddy Hendro Wibowo. "Antara Tanggung Jawab dan Karir (Gambaran Adversity Quotient pada Guru Pembimbing Khusus)." Humanitas , vol. 4.3, 2020.

[12] Watkins, Philip C., et al. "Gratitude and happiness: Development of a measure of gratitude, and relationships with subjective well-being." Social Behavior and Personality: an international journal, vol. 31.5, pp.431-451, 2003.

[13] Azwar, S. (2014). Metode Penelitian. Yogyakarta: Pustaka Pelajar.

[14] Froh, Jeffrey J., Giacomo Bono, and Robert Emmons. "Being grateful is beyond good manners: Gratitude and motivation to contribute to society among early adolescents." Motivation and Emotion, vol. 34.2, pp.144-157, 2010 
[15] Emmons, Robert A., and Michael E. McCullough, eds. The psychology of gratitude. Oxford University Press, 2004.

[16] McCullough, Michael E., Robert A. Emmons, and Jo-Ann Tsang. "The grateful disposition: a conceptual and empirical topography." Journal of personality and social psychology, vol. 82.1, pp.112, 2002.

[17] Wood, Alex M., Stephen Joseph, and John Maltby. "Gratitude predicts psychological well-being above the Big Five facets." Personality and Individual differences, vol. 46.4, pp.443-447, 2009. 